Etikonomi

Volume 16 (1), April 2017

P-ISSN: 1412-8969; E-ISSN: 2461-0771

Page $115-125$

\title{
MARKETING MIX IMPLEMENTATION IN SMALL MEDIUM ENTERPRISES: A STUDY OF GALERISTOREY ONLINE BUSINESS
}

\author{
Rora Puspita Sari ${ }^{1}$ \\ Universitas Padjadjaran Bandung \\ Email : rora.puspita@unpad.ac.id
}

\begin{abstract}
.
The purpose of this paper is to evaluate the implementation of marketing mix in online business company, whether the online business adopt solely the traditional marketing mix model or the internet factors is also included, since the business platform itself in on social media. Descriptive research and content analysis using interview and observation were used to analyse the marketing mix implementation in Galeristorey online business. Evidence suggested that Galeristorey implemented few elements of the marketing mix both the traditional marketing mix and the online marketing mix. The cause of the limited use of marketing mix elements because of the barriers faced by Galeristorey as an SME. Further researcher may widen the research sample and creates empirical study on the marketing mix implementation of online business that used social media as its main business platform.
\end{abstract}

Keywords: online business, marketing mix, small and medium enterprises

\begin{abstract}
Abstrak.
Tujuan dari penelitian ini adalah untuk mengevaluasi pelaksanaan bauran pemasaran di perusahaan bisnis online, apakah bisnis online hanya mengadopsi bauran pemasaran tradisional atau ada faktor internet yang dilibatkan. Penelitian ini merupakan penelitian deskriptif dan menggunakan analisis konten, menggunakan wawancara dan observasi untuk menganalisis implementasi bauran pemasaran dalam bisnis online Galeristorey. Hasil pemelitian menunjukean bahwa Galeristorey melaksanakan beberapa elemen dari bauran pemasaran baik bauran pemasaran tradisional dan bauran pemasaran online. Penyebab terbatasnya penggunaan elemen bauran pemasaran karena hambatan yang dihadapi oleh Galeristorey sebagai UKM. Saran untuk penelitian selanjutnya adalah dengan memperluas sampel penelitian dan melaksanakan studi empiris untuk meneliti pelaksanaan bauran pemasaran bisnis online yang menggunakan media sosial sebagai platform bisnis utama.
\end{abstract}

Kata Kunci: bisnis online, bauran pemasaran, UMKM

Received: October 7, 2016; Revised: January 17, 2017; Approved: February 10, 2017 
Marketing Mix Implementation

Rora Puspita Sari

\section{INTRODUCTION}

The utilisation of internet in Indonesia has risen significantly. Internet users have increased by 160\% from 30,000 users in 2010 to 78,000 users in 2015 (Internet World Stats, 2015). The increase of internet user means there is also an increase in the online transaction by internet users. It is predicted that the value of online commerce transaction in Indonesia will reach $\$ 4.5$ billion with 8.4 million active e-commerce users. One of the reasons of the increase of online commerce transaction in Indonesia is the shifting of offline store customer preferences to online stores (Tech Asia, 2016)

The growth of internet usage is along the line with the increase number of online business. The ease of access as well as minimum investment rate rather than opening an offline store contributed to the increase of online business maker in Indonesia. The increase of online shop opened a lot of business opportunity, especially in the fashion industry (Tanuwidjodjo, 2016)

In online fashion business, the usage of internet is more focused on the use of social media. There are several of social media platforms that are used to promote the fashion product to the potential customers. One of the popular social media platforms is the use of Instagram and Twitter. Instagram has proven to be an effective way to relate brands and consumers. Instagram has more followers than any other social media platforms by having 53\% of its users to follow their favourite brands (Thomas, 2016). While the traditional marketing mix, which consists of $4 \mathrm{P}$, it is argued that the $4 \mathrm{P}$ concept is still relevant to explain about the marketing mix in online business, with several adjustments (Dominici, 2009). The implementation of marketing mix is utterly important not only in traditional brick-and-mortar business, but also in e-business.

Galeristorey (GS) is an online store that focused its product on Moslem fashion line. GS represent online SME that places its product mainly in social media account. GS online platform focuses on Instagram and Twitter. The product of GS was distributed throughout Indonesia and Malaysia. As for its e-commerce transaction, GS was categorized as B2C company, since GS sell its product directly to customer, without any intermediaries. This research will examine how GS as the representative of the now trending online fashion SME in Indonesia implemented its marketing mix strategy, both the traditional 4P marketing mix as well as the online element of marketing mix. It is important to differentiate between the online SME and the online business that has more access to funding because the extent of the implementation might be varied. This research will add 
the understanding of the implementation of marketing mix strategy in SME, as well as other online fashion SME. As for the SME, this research will help the SME to learn the best way to maximize the implementation of marketing mix strategies to increase profit, customer satisfaction, and SME growth.

\section{METHOD}

A lot of study emphasized the importance of the implementation of marketing mix in SME. Marketing mix is the concept created by McCharthy (1964) as the means of executing marketing into practice. Marketing mix consist of four Ps namely as product, price, place, and promotion. Marketing mix is the common concept to measure how well the company practicing its marketing concept to increase profit (Goi, 2009). Previous research on the practice of marketing mix shows good impact of the implementation of marketing mix with firm performance. Study shows that the adoption of marketing mix by entrepreneur will enable them to have competitive advantage to their competitors (Mukaila Ayanda \& Joseph Adefemi, 2011). Another research shows that all the marketing-mix efforts positively affect the overall value of firm's brand equity (Kim \& Hyun, 2011). A study from Brei, D'Avila, Camargo, \& Engels (2011) shows that the firms who practice the adaptation of marketing mix has a better internationalization performance.

In online business, a modification of the $4 \mathrm{P}$ marketing concept has been made to tailored the needs of online business. Allen, et.al (2002) researched about the implementation of online marketing mix in multinational company in USA. The result of the research was the implementation of online marketing mix helped the company to gain more accurate and faster information about customer preferences, thus developing new customer base. In the terms of product, the company shall be more active in updating product information in online shopping site. In the terms of place, online marketing mix reduces the level of distribution channel. In the terms of place, online business creates a more flexible prices to fit market condition. Lastly online promotion gave more experience to the customer about the product.

Another research by Daniel, Elizabeth, Wilson, Hugh, Myers (2002) stated that online SMEs may also adopting marketing strategies by implementing several steps such as placing product information online, taking orders and receiving payment online, digital delivery, online after sales services, integrating online suppliers, online communication with customer, and online advertising. The adoption of online marketing strategies was related 
Marketing Mix Implementation

Rora Puspita Sari

to the use of electronic trading by the SMEs. The industry sectors with the highest levels of adoption is the service sector. Emdad, Ali F, Bhatt (2001) also stated the implementation of online advertising such as the use of audio, video, and graphics increases the virtual value chain. In addition, the flexibility in option pricing reducing the constraints of time and space.

The methodology used in this research is descriptive research. Descriptive research is a research that is made to find the value of independent variables without making any comparison or correlation between one variable and another. Descriptive method is a research that describes phenomena systematically (Musianto, 2002). Descriptive method is used to make an analysis of the implementation of marketing mix of the company. As to analyse deeper into the content of social media, content analysis will be done to analyse the online marketing mix implementation. Content analysis is a common technique used in the e-commerce research literature (Baack \& Singh, 2007; Merwe \& Bekker, 2003). In this research, content analysis is used to evaluate the implementation of marketing mix strategies done by GS by checking the content of GS social media that was related with marketing mix. The online and offline marketing mix checklist was listed in Table 1. After the analysis of the marketing mix implementation, the research will extent its analysis to the cause of the limitation from the common SME barriers.

Table 1. Marketing Mix Implementation Checklist

\begin{tabular}{|c|c|c|c|}
\hline $\begin{array}{l}\text { Marketing } \\
\text { mix }\end{array}$ & $\begin{array}{c}\text { Traditional Marketing } \\
\text { Checklist }\end{array}$ & $\begin{array}{c}\text { Online Marketing } \\
\text { Checklist }\end{array}$ & Explanation \\
\hline Product & $\begin{array}{c}\text { Physical Goods } \\
\text { Services } \\
\text { Experience } \\
\text { Events } \\
\text { People } \\
\text { Property } \\
\text { Organization } \\
\text { Information } \\
\text { Ideas }\end{array}$ & $\begin{array}{c}\text { Awards } \\
\text { Testimonies } \\
\text { Customer list } \\
\text { Customer comments } \\
\text { Warranties } \\
\text { Guarantees } \\
\text { Money-back offers } \\
\text { Customer services } \\
\text { Endorsement }\end{array}$ & $\begin{array}{l}\text { The company has some } \\
\text { elements of products }\end{array}$ \\
\hline Price & $\begin{array}{c}\text { Pricing goals } \\
\text { Product demands } \\
\text { Pricing nominal } \\
\text { Competitor cost analysis }\end{array}$ & Dynamic pricing & $\begin{array}{l}\text { Factors determining } \\
\text { product pricing strategy }\end{array}$ \\
\hline Place & $\begin{array}{c}\text { Zero level channel } \\
\text { One level channel } \\
\text { Two level channel } \\
\text { Three level channel } \\
\end{array}$ & $\begin{array}{c}\text { Own storefront } \\
\text { Online intermediaries } \\
\text { Social media }\end{array}$ & $\begin{array}{l}\text { Place the company sell the } \\
\text { product or the number of } \\
\text { channel used by company }\end{array}$ \\
\hline Promotion & $\begin{array}{c}\text { Advertising } \\
\text { Sales promotion } \\
\text { Public relations } \\
\text { Personnal selling }\end{array}$ & $\begin{array}{c}\text { Online advertising } \\
\text { Affiliate marketing } \\
\text { Video marketing } \\
\text { Social media marketing }\end{array}$ & $\begin{array}{l}\text { Promotion methods offline } \\
\text { and online }\end{array}$ \\
\hline
\end{tabular}




\begin{tabular}{cccc}
\hline $\begin{array}{c}\text { Marketing } \\
\text { mix }\end{array}$ & $\begin{array}{c}\text { Traditional Marketing } \\
\text { Checklist }\end{array}$ & $\begin{array}{c}\text { Online Marketing } \\
\text { Checklist }\end{array}$ & Explanation \\
\hline & Direct marketing & Search advertising \\
Event & SEO optimisation \\
Experience & Viral marketing & \\
Word of mouth & & \\
\hline
\end{tabular}

Sources : Compiled from Combe (2011); Stokes (2013)

\section{RESULT AND DISCUSSION}

As in Table 2, GS implemented limited elements of marketing mix. From the traditional point of view, the products offered by GS were Muslim fashion line that consists of skirts and head scarfs. GS used brand names "yasacloth" to define the product variants of skirt and head scarf. When delivering its product, GS used plastic packaging with the brand writen on it with paper label that has information of price and social media address on the product.

The pricing method that GS used was mark-up pricing. The mark-up percentage was determined after GS calculated the fixed and variable cost for each product. The markup percentage ranged from 30-70\% from the unit cost of each product. As for the place element, GS used zero level channel distribution to deliver its products to the customer without any intermediaries. Lastly for the promotion element, GS implemented two promotional mix components: interactive marketing and word of mouth. GS utilised twitter, Instagram as the platform of social media to promote its products. Word of mouth promotion was also implemented by promoting the products by all employees of GS.

GS used Twitter and mostly Instagram as its social media platform of online business. All of the checklisted elements of online marketing from Table 3 were derived from social media activities. Testimonies, comments, customer services and endorsements were features done by GS in its Twitter and Instagram account. Twitter@galeristorey was used to give general information regarding how to shop the product, newest product, and other information that related to GS. Customer may have two ways communication to GS regarding the product. Customer might not only acquire information online, but also replied the tweet to give comment or ask question regarding the content of the tweet. The followers of the account were 3060 followers by July 2016. Customer tweets mostly about product testimonials, customer comments regarding existing product and services, complaint, and question about the product and how to order the product. 
Table 2. Traditional Marketing Mix Implementation Checklist Result

\begin{tabular}{|c|c|c|c|}
\hline Marketing mix & $\begin{array}{c}\text { Traditional Marketing } \\
\text { Implementation Checklist }\end{array}$ & Checklist & Explanation \\
\hline \multirow[t]{9}{*}{ Product } & Physical goods & $\sqrt{ }$ & Skirt and headscarft \\
\hline & Services & $\sqrt{ }$ & Brands, delivery (packaging and labelling) \\
\hline & Experience & $\mathrm{x}$ & - \\
\hline & Events & $\mathrm{x}$ & - \\
\hline & People & $\mathrm{x}$ & - \\
\hline & Property & $\mathrm{x}$ & - \\
\hline & Organization & $\mathrm{x}$ & - \\
\hline & Information & $\mathrm{x}$ & - \\
\hline & Ideas & $\mathrm{x}$ & - \\
\hline \multirow[t]{4}{*}{ Price } & Pricing goals & $\sqrt{ }$ & $\begin{array}{l}\text { Mark-up pricing method to achieve targeted } \\
\text { income }\end{array}$ \\
\hline & Product demands & $\mathrm{x}$ & - \\
\hline & Pricing nominal & $\mathrm{x}$ & - \\
\hline & Competitor cost analysis & $\mathrm{x}$ & - \\
\hline \multirow[t]{4}{*}{ Place } & Zero level channel & $\sqrt{ }$ & $\begin{array}{l}\text { Sell directly to customer through social } \\
\text { media }\end{array}$ \\
\hline & One level channel & $\mathrm{x}$ & - \\
\hline & Two level channel & $\mathrm{x}$ & - \\
\hline & Three level channel & $\mathrm{x}$ & - \\
\hline \multirow[t]{8}{*}{ Promotion } & Advertising & $\mathrm{x}$ & - \\
\hline & Sales promotion & $\mathrm{x}$ & - \\
\hline & Public relations & $\mathrm{x}$ & - \\
\hline & Personnal selling & $\mathrm{x}$ & - \\
\hline & Direct marketing & $\mathrm{x}$ & - \\
\hline & Event & $\mathrm{x}$ & - \\
\hline & Experience & $\mathrm{x}$ & - \\
\hline & Word of mouth & $\sqrt{ }$ & Word of mouth by all employees \\
\hline
\end{tabular}

GS had Instagram account @galeristorey to promote its product. The Instagram account had 27,000 followers by July 2016. GS used the Instagram account to provide more complete information regarding GS and its product to the customer. The information provided by GS in its Instagram account was: company profile, GS contact, product details, product price, customer testimonials, and online shop guideline. In both of Instagram and Twitter accounts, GS engaged with fashion blogger to endorse its products. Fashion blogger helped to promote GS by post photos and videos of her using its product. Not only photos and videos posting, the fashion blogger was also answering and replying question and comment regarding GS product that was asked by customer.

Table 3. Online Marketing Mix Implementation Checklist Result

\begin{tabular}{|c|c|c|c|}
\hline $\begin{array}{l}\text { Marketing } \\
\text { mix }\end{array}$ & $\begin{array}{c}\text { Online Implementation } \\
\text { Checklist }\end{array}$ & Checklist & Explanation \\
\hline \multirow[t]{8}{*}{ Product } & Awards & $\mathrm{x}$ & - \\
\hline & Testimonies & $\sqrt{ }$ & $\begin{array}{l}\text { Customer filled the testimonies in Instagram and } \\
\text { Twitter }\end{array}$ \\
\hline & Customer list & $\mathrm{x}$ & - \\
\hline & Customer comments & $\sqrt{ }$ & $\begin{array}{l}\text { Customer made comments about the product in } \\
\text { comment on Instagram and Twitter }\end{array}$ \\
\hline & Guarantees & $\mathrm{x}$ & - \\
\hline & Money-back offers & $\mathrm{x}$ & - \\
\hline & Customer services & $\sqrt{ }$ & $\begin{array}{l}3 \text { employees handles all social media-related } \\
\text { matters (Q\&A, order and complaint handling) }\end{array}$ \\
\hline & Endorsement & $\sqrt{ }$ & Endorsed by selebgram \\
\hline
\end{tabular}


Etikonomi Vol. 16 No. 1 April 2017

\begin{tabular}{|c|c|c|c|}
\hline $\begin{array}{c}\text { Marketing } \\
\text { mix }\end{array}$ & $\begin{array}{c}\text { Online Implementation } \\
\text { Checklist }\end{array}$ & Checklist & Explanation \\
\hline Price & Dynamic pricing & $\mathrm{x}$ & - \\
\hline \multirow[t]{3}{*}{ Place } & Own storefront & $\mathrm{x}$ & - \\
\hline & Online intermediaries & $\mathrm{x}$ & - \\
\hline & Social media & $\sqrt{ }$ & Instagram and Twitter \\
\hline \multirow[t]{6}{*}{ Promotion } & Online advertising & $\mathrm{x}$ & - \\
\hline & Affiliate marketing & $\mathrm{x}$ & - \\
\hline & Video marketing & $\mathrm{x}$ & - \\
\hline & Social media marketing & $\sqrt{ }$ & Promotion via Instagram and Twitter \\
\hline & Search advertising & $\mathrm{x}$ & - \\
\hline & SEO optimisation & $\mathrm{x}$ & - \\
\hline
\end{tabular}

From the GS implementation of marketing mix, GS has implemented both traditional and online marketing mix. In the traditional marketing mix, GS has implemented all the $4 \mathrm{P}$ aspects, although the implementation was far from perfect. In product aspect, GS has implemented branding, packaging, labelling, product shape, product design, and styles. But other factors such as guarantee, features and services regarding the product were not yet defined. In pricing factors, GS has implemented markup pricing method, but the goals of the pricing were not clear and not decided yet by the owner. The demand analysis as well as the competitor cost analysis were also unclear. For the place element, GS occupied one distribution channel level, which was the direct to customer channel. And in the promotion element, interactive marketing was the main motor for the promotional activities, since GS had only virtual store. The implementation of marketing mix has succesfully attract followers in social media. This results aligned with Kim \& Hyun (2011) since GS has quite numbers of followers on social media, the more the brand followers means the bigger brand value accepted by users and customers. This results also aligned with study from (Brei et al., 2011) who stated that the adaptation of marketing mix resulted in a better internationalization performance. It can be seen that GS has already expands its market to Malaysia through its interactive marketing activities via Twitter and Instagram.

For the online marketing mix, GS used only social media platform as its main online business channel. There are a lot of online marketing tools that can be utilized by GS such as: dynamic pricing, affiliated marketing, viral marketing, SEO optimisation, search advertising and banner advertising. To apply not only social media, but also other online marketing tools will enhance target audience. The results of the limited implementation of online marketing mix is not aligned with Daniel, Elizabeth, Wilson, Hugh, Myers (2002) who stated that there are a lot of online marketing strategies that can be done by an SME. But this results were aligned partially with Bhatt \& Emdad (2001) who 
Marketing Mix Implementation

Rora Puspita Sari

stated that the use of audio, video and grahics increases virtual value chain. GS put a lot of pictures, tesmonies (video and audio) in its social media account. The frequent update of audio, video and graphics helped to attract more followers on social media. As followers are the potential customers, the more updated GS put its product, testimonials, video, or endorsement picture by artist, the more potential customer might be attracted to the product. But since GS failed to implement dynamic pricing method, GS also failed to gain advantage in reducing time and space constraint in updating price online. As GS applied very limited strategy of both traditional and online marketing mix, further question needs to be answered are the reason why GS applied limited marketing mix strategy for its business.

Firstly is the limited of working capital. To be able to exercise various methods of marketing promotions, GS needs additional funds more than its current working capital. From the interview with the owner, GS spent around 2\% from its total cost for the paid brand endorser. The owner did not apply more promotional channels because a lot of long-term promotion methods such as paid per click advertising or advertise in google was too expensive. Thus, GS needs extra working capital, especially for promotion budget. From the interview with the owner, the main sources of GS working capital for the operational process was from the owner funding and from the monthly retained earnings of GS. The owner was not able to add extra funding from external sources for the operation of the company. The limited working capital faced by GS was coherent with Lloyd-Reason, Ibeh, \& Deprey, (2009) stated that most SME suffered with shortage of working capital for improvement.

Limited working capital has strong relationship with limited access of funds from external party (Lloyd-Reason et al., 2009). GS capital was originated from internal source (owner capital). From the interview with the owner, the incapability to get external funds was because of the company does not have a legal status. The owner said that a lot of banks rejected GS proposal for credit issue because of the lack of legal status of the company as well as unclear tax status of the company and the owner. Thus, the limited access of finance was occured because legal barrier faced by GS.

Legal barrier was the third problem faced by GS. As GS was an online SME, the legal standing of the company is not yet defined. The owner of the company was not registered yet as the entrepreneur in the Indonesian Tax Directorate. GS company also did not have any legal status as a company. The legal barrier faced by GS was inline with 
Irjayanti \& Azis (2012) that stated that legal barrier was one of the factors hindered the development of Indonesian SME. The legal barries occured because of the low capability of the owner to make a long-term planning of the company. Low capability barrier was also consistent with Irjayanti \& Azis, (2012) as the reason why GS has limit its marketing mix implementation.

\section{CONCLUSION}

It can be concluded that from GS SME case study, there are still a lot of traditional marketing mix element that were not being implemented yet. Especially in the price, place, and promotion areas in the traditional marketing mix. As for the online marketing mix, since the platform of the business itself is based on Instagram and Twitter, the extend utilisation of the other marketing mix element might also be limited. The absence utilisation of marketing mix elements, both traditional marketing and online marketing, might be because of the nature of the GS itself as an SME. As an SME, GS suffered major limitations consists of limited working capital, limited financial access, legal barrier, and low capability.

\section{ACKNOWLEDGEMENT}

The completion of this research cannot be made without the help of Yulfa Agnia Sabha who help the author to collect the primary data.

\section{REFERENCES}

Allen, Eric, Fjermestad, J. (2002). E-commerce marketing strategies: an integrated framework and case analysis. Logistics Information Management, 14(1/2): 14-23.

Baack, D. W., \& Singh, N. (2007). Culture and web communications. Journal of Business Research, Vol. 60(3): 181-188.

Brei, V. A., D’Avila, L., Camargo, L. F., \& Engels, J. (2011). The influence of adaptation and standardization of the marketing mix on performance: A meta-analysis. $B A R$ Brazilian Administration Review, 8(3): 266-287.

Combe, C. (2011). Introduction to E-business: Management and Strategy. Oxford: Taylor \& Francis.

Daniel, Elizabeth, Wilson, Hugh, Myers, A. (2002). Adoption of E-Commerce by SMEs in the UK. International Small Business Journal, 20(3): 253-270.

Dominici, G. (2009). From Marketing Mix to E-Marketing Mix : a Literature Overview and 
Marketing Mix Implementation

Rora Puspita Sari

Classification. International Journal of Business and Management, Vol. 4: 17-24.

Emdad, Ali F, Bhatt, G. D. (2001). An analysis of the virtual value chain in electronic commerce. Logistics Information Management, 14(1/2), 78-85.

Goi, C. L. (2009). A Review of Marketing Mix: 4Ps or More? International Journal of Marketing Studies, Vol. 1(1): 2-15.

Internet World Stats. (2015). Indonesia Usage and Population Stats. Retrieved January 20, 2016, from http://www.internetworldstats.com/asia/id.htm

Irjayanti, M., \& Azis, A. M. (2012). Barrier Factors and Potential Solutions for Indonesian SMEs. Procedia Economics and Finance, Vol. 4: 3-12.

Kim, J. H., \& Hyun, Y. J. (2011). A model to investigate the influence of marketing-mix efforts and corporate image on brand equity in the IT software sector. Industrial Marketing Management, Vol. 40 (3): 424-438.

Lloyd-Reason, L., Ibeh, K., \& Deprey, B. (2009). Top barriers and drivers to SME internationalisation. Focus, Vol. 4: 1-32.

Merwe, R. Van Der, \& Bekker, J. (2003). A framework and methodology for evaluating ecommerce Web sites. Internet Research, Vol. 13(5): 330-341.

Mukaila Ayanda, A., \& Joseph Adefemi, B. (2011). Marketing Mix Practice as a Determinant of Entrepreneurial Business Performance. International Journal of Business and Management, Vol. 7(1): 205-214.

Musianto, L. S. (2002). Perbedaan pendekatan kuantitatif dengan pendekatan kualitatif dalam metode penelitian. Jurnal Management Dan Kewirausahaan, 4, 123-137.

Stokes, R. (2013). E-Marketing: The essential guide to marketing in a digital world. New York: Quirk Marketing (Pty) Ltd.

Tanuwidjodjo, S. (2016). Kualitas Layanan, Kepercayaan, dan Kepuasan Konsumen terbadap Loyalitas Konsumen OLSHOP di Surabaya. Retrieved from http://repository.wima.ac.id/308/2/bab 1.pdf

Tech Asia. (2016). Transaksi E-commerce Indonesia Tahun Depan 4.5 Miliar. Retrieved June 6, 2016, from https://id.techinasia.com/transaksi-ecommerce-indonesia

Thomas, A. (2016). How TOMS “One Day Without Shoes" Campaign Brings Staholders Together and Co-Creates Value for the Brand Using Instagram as A Platform. Journal of Fashion Marketing and Management: An International Journal, Vol. 5: 1-34. 